\title{
The Effect of Study Tour Activity in Teaching Junior High School Students Speaking Skill.
}

\author{
Muhammad Fauzi Bafadal, Ilham, Purna Irawan \\ a bcUniversity of Muhammadiyah Mataram, Indonesia, a Fauzi.bafadal@gmail.com
}

ARTICLE INFO

Article history:

Received

Revised

Accepted

Keywords:

Study tour, speaking, experiment

\begin{abstract}
Study tour is emphasize experiential learning and offer both group and self directed activities that enable learners to explore new territories, cultures, and people. Study tour is designed to be both fun and educational. Study tour activity help the students develop all four languages skills in the real life, and make speaking activities be more effective. In order, the purpose is to investigate of study tour activity has effect or not in teaching speaking skill at the first Grade of Islamic Junior High School, Al-Maarif Tumpak, District of Pujut. The subject of this study was conducted at the first grade students' of Islamic Junior High School Al-Maarif Tumpak. This study used purposive sampling. The writer took 25 students as a sample that divided into two groups, 13 students belong to the experimental group and 12 students belong to the control group. In collecting the data, this study used pre-test post-test as the research instrument then followed by analyzing the data using t-test formula. This study found that the mean score of post test of experimental group is higher than control group. It means that study tour activity has effect in teaching speaking skill. An analyzing data from the result between the deviations of mean scores of experimental group was 28,9 and control group was 21,7 . Then the result of the statistical analysis of $t-$ test in this study was 2,09. It was higher that critical values for t-table in degree of freedom (df) 23 is 2, $069(0,05 \%)$. Based on the result of this study, the alternative hypothesis (Ha) is accepted.
\end{abstract}

\section{Introduction}

Language is a system for the expression of meaning. It is primary function for interaction and communication (Jo McDonough and Christopher Shaw, 2003: 135). In Indonesia has applied English as the first foreign language learned at school. English has been teaching in each levels of education, so the students can apply to get the insight knowledge and ideas from foreign countries. Teaching English is more complicated than teaching Indonesia because the English teacher should be knowledgeable in describing or explaining about what the English purposes such as how to understand the meaning of words or sentences, how to understand speaking, how to pronounce and how to practice it. Speaking is one of the four language skills should be master by each learner. If the students want to speak English fluently, Harmer (2002: 6) suggests that they have to be able to pronounce correctly, master intonation, conversation, either transactional or interpersonal conversation.

Based on the Luoma Sari (2004: 9) said that speaking is usually judged during a face to face interaction, in real time, between an interlocutor and a candidate. It meant that interlocutor is listener and candidate is speaker, so that, in teaching and learning process, speaking is very important in teaching from the first time because it is prominent in use, the students use speaking when they express their ideas someone utters English sounds, they expect the response from each other, so students should master the elements of speaking, such as accent, grammar, vocabularies, fluency and comprehension. 
Based on the researcher pre observation on 12 of February the students in the Islamic Junior High School, Al-Maarif Tumpak, District of Pujut they are still less in mastering speaking skill. They have difficulties in speaking, for example when the teacher asked them to speak, they have difficulties to speak fluently without confident and also not interesting for the student. It makes them be lazy to join in English teaching and learning process. Beside the method of teaching English speaking make the students feel bored and not motivated because of the teacher takes too much rule in teaching, just give the student materials without any action to practice in speaking.

A review of existing literature Based on H. Douglas Brown (2001: 270) states that teaching speaking is started at teaching the students how to speak in English as their foreign language, for then ask them to be able to pronounce the new language accurately. It is continued then to guide students to a point where they can begin to judge whether their sound productions are correct or not. At this point, teacher is no longer primarily to correct, but he or she is supposed to encourage students to practice speaking the target language. Katula and Threnhauser (1999) in Morgan and Rogers stated that Study tours are a type of experiential education that has been significantly utilized in higher education in recent times.

There are some researchers has done which use study tour activity. The first previous research was done by Annette Morgan and Nicole Wilson-Rogers (2012) explain about "The Use of Study Tours and Reflective Journals as Learning Tools" in Second Semester at Curtin University. He concluded that study tours are one way of igniting student interest in taxation. The Canberra study tour was designed to encourage students to reflect on the lifecycle of a tax from the inception of a taxation policy to the review of the application of a taxation law by the Courts. It also helped to build a sense of community amongst a group of taxation students and allowed them to reflect upon some of their broader professional goals for their career in taxation.

Second previous research was done by John J. Matt (2013) Department of Educational Leadership the University of Montana has conducted a study "International Study Tour Groups". He concluded that Participation with international study tour groups can transform all participants and enrich the individual. The transformational outcomes from international study tours can encompass a variety of effects involving increased cultural awareness. These effects may range anywhere from cultural conflicts and challenges that arise, to deep human connections that are made between individuals of different cultural backgrounds.

Third previous research was done by to Yue Cui (2015) Faculty of Economics University of Ljubljana Slovenia, Stated in His Study "Finding the Balance between Learning and Travel Experience in Student Field Trips". He concluded that study shows improve the satisfaction of overall experience in student field trips. The model of student field trip experience for informal study and the "service experience model in tourism" the positive impact of learning experience and travel experience on the satisfaction of overall experience was proven. Travel experience should not be ignored by researchers and school trip organizers.

\section{Method}

The research design of this study was Quasi Experimental Design. According to Sugiyono (2014: 114) stated "it is developing from the experimental design. This design has a control group, but that group does not have full functions to control the variables outside of the research implementation". Where there is no randomization for experimental group. The population of this research is the student in the first grade students' of Islamic Junior High School Al-Maarif Tumpak in academic year 2017-2018 that consist of 25 students. They are distributed into two classes (VII A and VII B).

The sample of this research was the First Grade Students' of Islamic Junior High School AlMaarif Tumpak. The researcher took all classes from the two classes at the first grade students. They were VII A as experimental group and VII B as control group. Where VII A as experimental group (with treatment) and VII B as control group (without treatment), so, the total number of sample was 25 students; 13 students for the experimental group and 12 students for the control group. In this research used purposive sampling because these classes were less in speaking and this procedure appropriate with the purpose of this research that was to investigate the used of study tour activity in teaching speaking.

\section{Data Collection}

In this step the researcher provided treatment to the experimental groups. The researcher treated the students in experimental group with study tour activity and control group not using study tour. 
First, teacher prepared the students and told the students what they do and then teacher chooses some speaking materials such as Greeting, Self-Identity, Introduce to the other people, Describing some tourism object with composed the lesson plan for teaching learning activity. The students was studied in the class to prepared what students will do when study tour, then after teacher finished taught some materials in every meeting, teacher asked students to practice one by one or a group in front of the class.

The researcher brought experimental group to the beaches for speaking practiced based material that related with study tour activity and asked them looked for foreigner. Then students and teacher together was visited some place such as Mawun beach and Mawi beach to study tour and practice directly with native speaker. Teacher look for native speaker or students look for their self to practice directly in the real situation based on materials and concepts that teacher given until two minutes or more. The researcher took note from each student's performance, record and documentation them when practice speaking English with foreigner and then the researcher was score them.

\section{Results and Discussion}

\section{A. Findings}

In this part, the writer presents the statistical computation of obtained data namely experimental group (X) and control group (Y). Later, the discussion cover the calculation of mean scores of both finding. The statistical computation covers both experimental group and control group. The data which obtained as the result of the study showed that the use of study tour activity in teaching speaking skill has effect or not in teaching speaking at the first grade students of Islamic Junior High School, Al-Maarif Tumpak, District of Pujut in Academic Year 2017/2018.

Instrument test based on criteria such as: accent, grammar, vocabulary, fluency and comprehension. The result analysis of the data pre-test and post-test class experiment with class control showed like in the table bellow.

Table 4.1 the score of the experimental group

\begin{tabular}{|c|c|c|c|}
\hline No & Pre-test & Post-test & The Deviation Score \\
\hline 1 & 25 & 64 & 39 \\
\hline 2 & 32 & 51 & 19 \\
\hline 3 & 22 & 54 & 32 \\
\hline 4 & 29 & 50 & 21 \\
\hline 5 & 19 & 53 & 34 \\
\hline 6 & 26 & 64 & 38 \\
\hline 7 & 19 & 60 & 41 \\
\hline 8 & 23 & 57 & 34 \\
\hline 9 & 30 & 36 & 6 \\
\hline 10 & 20 & 42 & 22 \\
\hline 11 & 27 & 55 & 28 \\
\hline 12 & 24 & 50 & 26 \\
\hline 13 & 24 & 60 & 36 \\
\hline Average & 24.62 & 53.54 & 28.92 \\
\hline
\end{tabular}

Table 4.2 the score of the control group

\begin{tabular}{|c|c|c|c|}
\hline No & Pre-test & Post-test & The Deviation \\
\hline 1 & 31 & 46 & 15 \\
\hline 2 & 34 & 54 & 20 \\
\hline 3 & 34 & 50 & 16 \\
\hline 4 & 33 & 47 & 14 \\
\hline 5 & 19 & 50 & 31 \\
\hline 6 & 38 & 60 & 22 \\
\hline 7 & 19 & 51 & 32 \\
\hline 8 & 27 & 58 & 26 \\
\hline 9 & 30 & 56 & 13 \\
\hline 10 & 20 & 42 & 18 \\
\hline 11 & 37 & 50 & 21.67 \\
\hline 12 & 30 & 48 & 31.00 \\
\hline
\end{tabular}


Based on the result above, there were different of pre-test and pos-test score of experimental and control group. For experimental group, all the result have been calculated based on the score of pretest and post-test after they were taught by using study tour. Whereas, the control group the result have been calculated based on the score of pre-test and post-test without being taught by study tour.

\section{The Calculation of Mean Score}

The writer used the following formula to look for the mean score of pre-test and post-test for both experimental and control group.

1. The mean score of experimental group (Mx)

$$
\begin{aligned}
& M x=\frac{\sum x}{N} \\
& M x=\frac{376}{13} \\
& M x=28,9
\end{aligned}
$$

2. The mean score of control group (My)

$$
\begin{aligned}
& \text { My }=\frac{\sum y}{N} \\
& M y=\frac{260}{12} \\
& M y=21,7
\end{aligned}
$$

From the calculation above, it was found that the mean score of experimental group is 28,9 it is higher than the mean score of control group that is 21, 7. It showed that the experimental group can answer the question better than the control group. Since the material was the same for both group and presented by same teacher and same time length, the different was the writer applied study tour activity for experimental group while in control group without study tour activity. Based on the table above, the writer looked for the standard deviation score for both group by using this formula:

3. Standard Deviation Experimental Group

$$
\begin{aligned}
& \Sigma x^{2}=\Sigma x^{2}\left(\frac{\Sigma x^{2}}{N}\right) \\
& =12060-\frac{(376)^{2}}{13} \\
& =12060-10.875,1 \\
& =1.184,9
\end{aligned}
$$

\section{Standard Deviation Control Group}

$$
\begin{aligned}
& \Sigma y^{2}=\Sigma y^{2}\left(\frac{\Sigma y^{2}}{N}\right) \\
& =6160-\frac{(260)^{2}}{12} \\
& =6160-\frac{67.600}{12} \\
& =6160-5633,3 \\
& =526,7
\end{aligned}
$$

5. The Calculation of T-test

After finding square deviation, the result of data analysis score is calculated to the score of t-test formula. 


$$
\mathrm{T}-\text { test }=\frac{\mathrm{Mx}-\mathrm{My}}{\sqrt{\frac{\sum x^{2}+\sum y^{2}}{(\mathrm{Nx}+\mathrm{Ny})-2}\left[\frac{1}{\mathrm{Nx}}+\frac{1}{\mathrm{Ny}}\right]}}
$$

Where: $\quad$ M: The mean score of each group

$\mathrm{N}$ : The number of sample

$\mathrm{X}$ : The standard deviation score of control group

Y: the standard deviation score of control group

$\sum$ : the sum of......

$\sqrt{ }$ : the root of....

(Arikunto, 2014: 306)

$$
\begin{aligned}
& t-\text { test }=\frac{\mathrm{MX}-\mathrm{MY}}{\sqrt{\frac{\sum x^{2}+\sum y^{2}}{(\mathrm{NX}+\mathrm{NY}-2}\left[\frac{1}{\mathrm{NX}}+\frac{1}{\mathrm{NY}}\right]}} \\
& \mathrm{t}=\frac{28,9-21,7}{\sqrt{\frac{1.184,9+526,7}{(13+12)-2}\left[\frac{1}{13}+\frac{1}{12}\right]}} \\
& t=\frac{7,2}{\sqrt{\left[\frac{1.711,6}{23}\right][0,16]}} \\
& \mathrm{t}=\frac{7,2}{\sqrt{[74,4][0,16]}} \\
& \mathrm{t}=\frac{7,2}{\sqrt{11,904}} \mathrm{t}=\frac{7,2}{3,45} \\
& \mathrm{t}=2,09
\end{aligned}
$$

The analysis of the data in this research is aimed to find out the deviation mean scores analysis it is referred to the score of t-test 2,09. Now, it is to be interpreted to find out if it is significant or not. Before the writer check the table of distribution. Firstly, the writer determines the degree of freedom (df) that is $x+y-2=13+12-2=23$. Based on the table of level significance have been pointed out, the coefficient t-test is directly checked on the table of $t$ distribution. Based on the table, the critical value of t-table on the level of significance t $0,05 \%$ is 2,069 . So it is found that 2,09>2, 069 .

Based on the data analysis above, it was found that the result of t-test is higher than t-table. It means that alternative hypothesis which stated that study tour activity has effect in teaching speaking is accepted. Meanwhile the null hypothesis which stated that study tour activity has not effect in teaching speaking is rejected.

\section{B. Discussion}

This study is aimed to describe the speaking test achievement for the first grade students of Islamic Junior High School, Al-Maarif Tumpak, District of Pujut in class VII A (Experimental group) and VII B (Control group). Based on the research method that was explained above, this research was divided into three steps. Firstly, the researcher gave pre-test to the students to know the ability of the students' before they got treatment. Secondly, the researcher gave the students treatment what they will do when study tour activity, they were taught some speaking materials, they went to some tourism object such as Mawi and Mawun beach for study tour activity, after that the students more active and more interest to learn speaking. Last, the researcher gave them post-test after they got treatment. 
The improvement of their speaking could be seen in their pre test and post test result. The result of average pre test of experimental group and control group were 24,6 and 29,3. From the result, it was found that the ability of both groups were relatively the same. Furthermore, based on pre test scores, we can see the students have some difficulties in speaking test especially to show their idea and shy to speak. They were still so halting and fragmentary when their told about their self-identity.

Student example: Rohaini's pre-test

Good morning, My Friend. Let me introduce myself. My name Rohaini, but you can call

Rohan. I am Indonesian. I live at Bongkol. I am born in Tumpak on January 25th, 2003. So

I am 12 year old now. I study at Islamic Junior High School, Al-Maarif Tumpak. My hobby cooking.

Explaination :

In this paragraph above there were errors sentences or grammar errors she made, let's check correctly.

Good morning, My Friend: she should say, My Friends, there is no plural S, because there are many friends in her classroom, more than one person.

My name Rohaini: she should say, my name is Rohaini, because there is no to be is in this sentence.

You can call Rohan: she should say, you can me Rohan, because there is no personal pronoun (Objective/accusative) me in this sentence.

I am born in Tumpak on January 25th, 2003: she should say, I was born in Tumpak on January 25th, 2003. Because she did not use past tense was in this sentence.

I am 12 year old now: she should say, I am 12 years old now. There is no plural $\mathrm{S}$ in this sentence.

My hobby cooking: she should say, my hobby is cooking, there is no to be is she used in this sentence.

For pre-test Rohaini get scores: 2 for accent, 1 for grammar, 1 for vocabulary, 3 for fluency and 2 for comprehension. Where, in accent for level 2 explain that frequent gross errors and a very heavy accent make understanding difficult, require frequent repetition, for grammar in level 1 is grammar almost entirely inaccurate except in stock phrases, for vocabulary in level 1 is vocabulary inadequate for even the simplest conversation, for fluency in level 3 explain that speech is frequently hesitant and jerky, sentence may be left uncompleted and for comprehension in level 2 is understands only slow, very simple speech on common social and touristic topic, requires constant repetition and rephrasing.

After gave the treatment, the students ability in speaking was improved which was proved by the result of the post-test. The post-test score for experimental group was 53,5 there was an upgrading point from the pre test. Meanwhile, the control group, those who taught using other activity, also gained their score their score into 51. Yet, based on the score, it can be that the score of experimental group is higher than the control group.

Student's example: Rohaini's post-test

Good morning, my friends. Let me introduce myself. My name is Rohaini, but you can call me Rohan. I am Indonesian. I live at Bongkol. I was born in Tumpak on January 25th, 2003. So I am 12 years old now. I study at I study at Islamic Junior High School, Al-Maarif Tumpak. My hobbies is reading and cooking. I have two sisters and one brother. My father is farmer and my mother is house wife. Nice to meet you

Well my opinion about Mawun beach, Mawun beach very nice beach for holiday, you can relax and enjoy. You can laying down, doing sun bathing, walking along the beach till swimming.

Explaination:

In this paragraph above there were errors sentence or grammar errors she made, let's check correctly. 
My hobbies is reading and cooking: she should say, my hobbies are reading and cooking. She did not use correct to be because more than one hobby.

My father is farmer and my mother is house wife: she should say, My father is a farmer and my mother is a house wife. there is no article $\mathrm{A}$ in this sentence she used.

For pre-test Rohaini get scores: 3 for accent, 4 for grammar, 4 for vocabulary, for fluency and 3 for comprehension. Where, in accent for level 3 explain "Foreign accent" requires concentrated listening and mispronunciation lead to occasional misunderstanding and apparent errors in grammar or vocabulary, for grammar in level 4 is an occasional error showing imperfect control of some patterns but no weakness that causing misunderstanding, for vocabulary in level 4 is professional vocabulary adequate to discuss special interest, general vocabulary permits discussion of any nontechnical subject with some circumlocutions, for fluency in level 5 explain speech is effortless and smooth, but perceptibly non-native in speed and evenness and for comprehension in level 3 can understand careful, somewhat simplified speech directed to him, with considerable repetition and rephrasing.

Based on the result of analysis of the deviation score of pre-test and post-test, continued to the calculation the computation of the mean scores, then we can see which group obtained the better scores after the treatment. For the experimental group the mean scores is 28,9 and for the control group is 21,7 . It showed that the score of experimental group was higher than control group.

To check the significant effect of the treatment, the researcher analyzed by using t-test formula. The result of t-test was 2,09. Then, the researcher checked the critical value on the t-table of significant level $0,05 \%$ was 2,069 . From the result, it was found that $t$-test was higher than $t$-table $(2,09>2,069)$. It means that there was significant effect of using study tour activity in teaching speaking.

Besides, study tour makes the class situation more interesting, fun and alive because they are thinking that after study they will visit the some tourism object. Students were speaking and took notes individually then practice together to the foreigner. The practice makes students focus because they have to face to face with foreigner and also students actively involved in the learning process. Practice to the foreigner can reduce students' anxiety because they have to perform only in front small audience. As Wajnryb in Vasiljevic (2010:41) stated that this approach may be particularly suitable for those in which students tend to be shy and are not used to voicing their ideas in front of the whole class.

Study tour is one of activity that can be used outside the classroom. Teacher discusses with the students for prepare the materials in the classroom. The students had one week or more to practice at home, after that student had tour to the beach or another tourist object and perform to practice with foreigner. This activity is effective in facilitating their speaking.

To be a good speaker in the sense, that students are able to convey their thought, feeling, ideas and opinion, view honestly and clearly. While, to be a good listener, I the sense that the students are ready and able to listen what talked by other participant seriously. By speaking, the students can create a heightened sense of accomplishment and promote self-confidence. Rather than trying to artificially, remove this tension, the activity makes constructive uses of the tension as a motivation conditioning agent.

From the explanation above, it can be conclude that the students' speaking skill after they were taught by using study tour activity is better than before being taught using study tour activity. It showed by the t-test was higher than t-table $(2,09>2,069)$ which mean the alternative hypothesis $(\mathrm{Ha})$ is accepted. It means that there are significant scores at the first grade students of Islamic Junior High School, Al-Maarif Tumpak, District of Pujut before using study tour activity and after using study tour activity.

\section{Conclusion}

Based on result of the study, it could be concluded that the use of study tour activity has effect in teaching speaking at the first grade students of Islamic Junior High School, Al-Maarif Tumpak, District of Pujut in academic year 2017/2018. It showed that using study tour activity in teaching speaking students more active and interesting to learning speaking in the classroom. This skill has been proved by analyzing data from the result between the deviations of mean scores of experimental group was 28,9 and control group was 21,7 . 
Then the result of the statistical analysis of t-test in this research was 2, 09. It was higher that critical values for t-table in degree of freedom (df) 23 is 2,069 (0, 05\%). From this fact, it was clear that mean score of both groups has a difference. It means the alternative hypothesis (Ha) was definitely accepted. The use of study tour activity in teaching speaking at first grade students of Islamic Junior High School, Al-Maarif Tumpak, District of Pujut has effect.

\section{References}

1. Arikunto, Suharsimi. 2014. Prosedur Penelitian Suatu Pendekatan Praktik. Jakarta: Rineka Cipta.

2. Cui Yue. 2015. A Master Thesis. Finding The Balance Between Learning And Travel Experience In Student Field Trips. Faculty Of Economics University Of Ljubljana Slovenia: published

3. H. Douglas Brown. 2001. Teaching by Principles an Interactive Approach to LanguagePedagogy. NY: Addison Wesley Longman Inc.

4. Harmer Jeremy. 2002. The Practice of English Language Teaching. England: Pearson Education limited, 3rd Ed.

5. Annette Morgan and Nicole Wilson-Rogers, 2012. A Journal. The use of Study Tours and Reflective Journals as learning tools. Curtin University

6. Jo McDonough and Christopher Shaw. 2003. Materials and Methods in ELT: A Teachers Guide. UK: Blackwell Publishing.

7. John J. Matt, 2013. A Journal. International Study Tour Groups. Department of Educational Leadership the University of Montana

8. Louma Sari. 2004. Assessing Speaking. Cambridge: Cambridge University Press

9. Sugiyono, 2014. Kualitatif Metode Penelitian Kuantitatif Dan R\&D. Bandung: Alfabeta.

10. Vasiljevic, Zorana 2010. Dictogloss as an Interactive Method of Teaching Listening Comprehension to L2 Learners. English Language Teaching. Vol.3.No. 1. p. 41. 
Journal of English Language Teaching and Linguistics (JELTL)

ISSN 2339-2940 /FKIP UM Mataram

Vol. 11 No. 1 June 2018 